\title{
Evaluation of anti-inflammatory, immunomodulatory effects and celiac-like side effect of olmesartan medoxomil as a vitamin $D$ receptor agonist and angiotensin II receptor blocker
}

\author{
Yelda KOMESLI 1 * iD, Ercument KARASULU 2, 3 (iD) \\ 1 Department of Pharmaceutical Technology, Faculty of Pharmacy, Altınbaş University, Bakırköy 34147, İstanbul \\ Turkey. \\ 2 Department of Pharmaceutical Technology, Faculty of Pharmacy, Ege University, Bornova, 35040, Izmir, Turkey. \\ 3 Center for Drug R\&D and Pharmacokinetic Applications (ARGEFAR), Ege University, 35040, Izmir, Turkey \\ * Corresponding Author. E-mail: yelda.komesli@altinbas.edu.tr (Y.K.); Tel. +90-212-709 4528.
}

Received: 16 May 2021 / Revised: 24 October 2021/ Accepted: 25 October 2021

\begin{abstract}
Prodrug Olmesartan Medoxomil (OM) is an angiotensin II receptor blocker (ARB) and a vitamin D Receptor (VDR) agonist. Reducing the inflammation and improving the immune system OM prevents organ damage. Angiotensin II receptor blockers (ARBs) can raise serum and tissue levels of the membrane-bound form of monocarboxypeptidase angiotensin converting enzyme 2 (ACE2). Increased ACE2 activity causes the balance in the RAAS to shift towards the positive ACE2-Ang-(1-7). Therefore It can be useful with anti-inflammatory, anti-fibrotic and anti-oxidative stress signals in the treatment of immune system diseases. OM is also known to have adverse effects, such as celiac-like enteropathy which was accepted by the FDA. The mechanism of OM's intestinal injury is thought to be the excessive consumption of the enzymes POX1 and carboxymethylenebutenolidase, which are also responsible for the the digestion of gliadin during the hydrolysis of the drug. Cell-mediated immune response and genetic predisposition are the other factors. Our histopathological findings of olmesartan-induced celiac-like enteropathy in rat intestines were increased mononuclear cell infiltration and villous atrophy. In this study these various action mechanisms of OM and its possible immun system booster effects were discussed. The findings of our rat intestines after exposure to OM-Suspension supported and correlated clinical findings of OM. In conclusion, by making extensive evaluations, OM can be a promising immunomodulator agent in immune system diseases.
\end{abstract}

KEYWORDS: ARB; vitamin-D; VDR-agonist; ACE2; Ang-(1-7); PON1; celiac-like-enteropathy; immunotherapeutic.

\section{INTRODUCTION}

Angiotensin II receptor blockers (ARBs) can raise serum and tissue levels of the membrane-bound form of monocarboxypeptidase angiotensin converting enzyme 2 (ACE2). Whether ACE2-enhancing drugs such as ACEIs and ARBs increase the possibility of infection and disease severity is the subject of many studies. Commonly used ACE inhibitors (ACEIs) and angiotensin-II receptor blockers (ARBs) in patients with hypertension, cardiovascular disease, and/or diabetes increase serum/tissue ACE2 levels. It has been reported that ARBs, ACEIs, RAAS inhibitors, statins, PPAR-c agonists, GLP-1 agonists and non-steroidal antiinflammatory drugs raise ACE2 mRNA expression and/or protein levels in various tissues or plasma of animals or humans (1). Olmesartan medoxomil (OM) is an angiotensin II receptor blocker (ARB) and has pleiotropic effects unrelated to its primary mechanism of action as a prodrug (2). OM is an AT1 subtype selective antagonist of angiotensin-II receptors. Stimulating the vitamin D receptor (VDR), olmesartan, is also a VDR agonist. It reactivates the immune system, restores VDR competence, corrects irregular vitamin D metabolism and reduces inflammatory symptoms (3). Olmesartan acts similarly to 1,25(OH)2D to reduce inflammation and improve the immune system. VDR and RAS receptors are located in the same tissues. Endogenous VDR ligand 1,25(OH)2D down-regulates RAS by suppressing renin gene expression to reduce inflammation via the nuclear factor-kappa B pathway and lowers angiotensin II (a peptide involved in the inflammatory process) with the similar effect of OM (3)(4)(5). Changes in RAS efficiency are inversely proportional to changes in VDR activation and there is a feedback relationship between these systems.

How to cite this article: Komesli Y, Karasulu E. Evaluation of anti-inflammatory, immunomodulatory effects and celiac-like side effect of olmesartan medoxomil as a vitamin D receptor agonist and angiotensin II receptor blocker. J Res Pharm. 2022; 26(1): 63-74. 
Inappropriate stimulation of RAS is associated with the pathogenesis of hypertension, heart attack, and stroke(6). ACE2 is a homeostasis regulator in the cardiovascular and respiratory systems and is a component of the renin-angiotensin-aldosterone system (RAAS).

$\mathrm{OM}$ is also known to have adverse effects, such as celiac-like enteropathy which was accepted by the FDA (According to safety announcement UCM359496). Link between OM and celiac effect was first defined by Rubio-Tapia et al in 2012 (7)(8). This histopathological finding of celiac-like side effects are severe intestinal villous atrophy with intraepithelial lymphocytosis, increased subepithelial collagen and inflammation of lamina propria. The cessation of OM causes complete improvement of both clinical and histological features. The diagnosis of celiac disease is supported by a positive antibody test (deamidated gliadin peptide, antiendomysial antibodies and tissue transglutaminase) and symptomatic and histological response to a gluten-free diet (9)(10)(11)(12)(13)(14). The mechanism of intestinal injury of OM is thought to be a cellmediated immune response and genetic predisposition. PON1 and carboxymethylenebutenolidase enzymes are responsible for hydrolising of olmesartan (Figure 1)(82). These enzymes are also responsible for deficient gliadin degradation in celiac patients. In patient with autoimmun disorders, OM restores VDR competence, phagocytosis causes to bacterial death; inflammation is temporarily increased by cytokine reaction to microbial endotoxins and cellular debris from dead host cells and bacteria. In this study these various mechanisms of action of $\mathrm{OM}$ and its possible effectiveness in immune system diseases were examined in the context of case reports and literature and then we associated with histopathological findings of our experiments in rats. During histopathological examinations, two different pharmaceutical forms of OM (Suspesion and SMEEDS forms) were evaluated, and the effect of inflammation was compared.

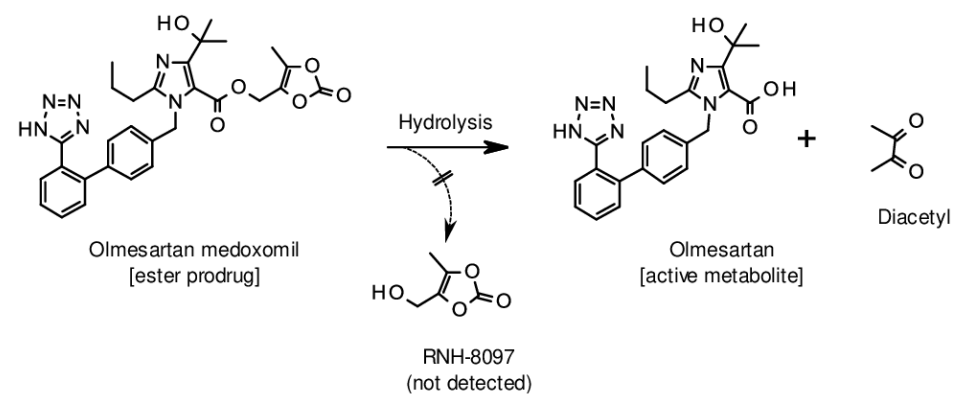

Figure 1. Hydrolisis of Olmesartan Medoxomil.

\section{RESULTS}

\subsection{Histopathological findings}

Histological studies were performed on albino 18 male normotensive Wistar Rats (160-180 g). After one month of exposure of OM-SMEDDS and OM-suspension, intestinal samples were taken from control group, OM-SMEDDS and $1.3 \mathrm{mg} / \mathrm{kg}$ OM-suspension orally administered group rats. The duodenum was used as the intestinal segment [15]. Histological examinations of rat intestine indicated that OM-SMEDDS treated rats and control group had no enteropathy findings while the OM-Suspension-treated group showed enteropathy findings with increased mononuclear cell infiltration and villous atrophy (Figure 2). OM-SMEDDS reduced the contact of OM with the intestines because of its lipophilic characteristics. This effect of SMEDDS can be explained by increased bile secretion in the gastrointestinal tract, dividing into mixed micelles, increasing lymphatic transport, and modulating enterocyte-based enzyme and carrier systems [16][17]. Throughout the experiment, SMEDDS did not cause diarrhea or weight loss compared to OM-Suspension. This finding suggests that the SMEDDS will prevent celiac-like enteropathy.

\section{DISCUSSIONS}

Angiotensin receptor blockers (ARBs) have been shown to modulate VDR activation through in silico molecular modeling [18]. OM is an angiotensin receptor blocker and also a non-vitamin D VDR ligand that reactivates the immune system, restores VDR competence, improves irregular vitamin D metabolism, and reduces inflammatory symptoms. Vitamin D is a steroid hormone that regulates the immune system. OM 
regulates the vitamin $\mathrm{D}$ receptor and decreases the high 1,25(OH)2D to improve the function of the innate immune system [18][3].

$\mathrm{OM}$ has a Ki value (the binding affinity between the inhibitor and the enzyme) in the low nanomolar range similar to the Ki values of natural VDR ligands and reduces the high 1,25(OH)2D by VDR mediated effects. The up-regulated VDR transcribes CYP24A1 and CYP3A4 enzymes that reduce 1,25(OH)2D production [19] [20]. It also represses CYP27B1 (the enzyme that hydroxylates $25(\mathrm{OH}) \mathrm{D}$ to $1,25(\mathrm{OH}) 2 \mathrm{D})$ so less $1,25(\mathrm{OH}) 2 \mathrm{D}$ is produced. A decrease in elevated 1,25(OH)2D prevents systemic inflammation. In this context $\mathrm{OM}$ improves glycemic control and insulin resistance by its antiinflammatory action [21]. OM also reduces serum levels of inflammatory markers; h-CRP, h-TNFa, IL-6, MCP-1 [22]. Blocking ACE OM induces potent regulatory $\mathrm{T}$ cells and modulates TH1- and TH17-mediated autoimmunity [23]. Besides, by blocking angiotensin II receptor OM increases bone mass [24][25]. OM, similar to 1,25(OH)2D, reduces inflammation and improves the immune system. VDR and RAS receptors are distributed in almost the same tissues. Endogenous VDR ligand 1,25(OH)2D downregulates RAS by suppressing renin gene expression to reduce inflammation via the nuclear factor-kappa B pathway [26]. OM similarly reduces angiotensin II (a peptide involved in the inflammatory process) [5]. Improper stimulation of RAS is associated with the pathogenesis of hypertension, heart attack, and stroke [6]. Changes in RAS activity and activation of the VDR is inversely related and have a feedback relationship. As a result, OM has dual activity in this cycle by blocking angiotensin II and stimulating the VDR and is more effective than the others. As an indicative of the Jarisch-Herxheimer reaction (JHR), olmesartan causes an increase in inflammatory symptoms in patients with autoimmune disorders and inflammatory symptoms [3][27]. OM restores VDR capability and phagocytosis leads to bacterial death. Consequently, inflammation is temporarily increased by cytokine reaction to microbial endotoxins and cellular debris from dead host cells and bacteria [28]. This immunopathology is a manifestation that OM is a VDR agonist [29][23][30]. Blocking receptors of the innate immune system can be useful in controlling infection and associated immunopathology [31]. Documented beneficial effects of OM, including its ability to reduce cardiovascular and kidney disease, prevent migraine, and reduce oxidative stress, also suggest that it may play a key role in resolving chronic systemic inflammation [32][33]. These uses of OM, which has a good safety profile, are off-label [3][34]. Microbes survive by dysregulating the VDR and slowing down immune reactivity. Chronic conditions can be improved by restoring VDR function using immunotherapy with OM as a novel VDR ligand [35][36]. As an alternative avoiding immunosuppressants and high $25(\mathrm{OH}) \mathrm{D}$ also improves immune system function [37][38][39]. Our histopathological findings of OM induced celiac-like enteropathy in rat intestines were intense mononuclear cell infiltration and villous atrophy. The mechanism of intestinal injury of OM is thought to be a cell-mediated immune response and genetic predisposition and hydrolising process with the carboxylesterases enzymes which are also are involved in the breakdown of gliadine. It is difficult to differentiate olmesartan-related enteropathy findings and histopathology from celiac disease [40]. In a systematic review performed by Burbure, findings from different case series were evaluated. In a total of 104 cases, patients who had been using OM for 1 month to 11.5 years were examined. HLDQ/ HLDQ8 gene was detected in 70\%, villous atrophy was detected in $100 \%$ and IEL was detected in $70 \%$ of the cases [41]. 30\% collagen sprue, $27 \%$ microscopic colitis and $41 \%$ lymphocytic or collagen gastritis were detected in cases. $95 \%$ of patients recovered after discontinuation of OM treatment. The diagnosis of celiac is supported by a positive antibody test (deamidated gliadin peptide, antiendomysial antibodies and tissue transglutaminase) and symptomatic and histological response to a gluten-free diet [42][43][44]. Genarally, villous atrophy, severe enteropathy, lupus, positive anti-TG2 deposits, increased CD3+gammadelta+ intraepithelial lymphocytes and reduced CD3- were observed in many olmesartaninduced cases and HLA-DQ2, HLA-DQ8 were positive [36]. Histopathological changes and clinical findings involving autoimmune disorders improved after discontinuation of $\mathrm{OM}$. This severe enteropathy may be due to the different affinity of OM on a VDR, PPAR and CCR $2 b$ receptors that can modulate the immune system [14][11][45][46][47][48][40][7][41][49][50][51][52]. Case reports of patients taking other angiotensin receptor blockers like valsartan, irbesartan, telmisartan, eprosartan, losartan, and candesartan demonstrated a profound celiac-like enteropathy findings and villous atrophy are also exist [44][53][54][55].

Olmesartan-induced celiac-like enteropathy was determined with endoscopy and computer tomography methods by Khan et al. and Carneiro et al [56][57]. Lagana identified some histological changes related with $\mathrm{OM}$ in the intestine [58]. Related with pathogenesis of olmesartan-induced enteropathy, over expression of IL15 and disruption of the tight junction protein ZO-1 protein were determined in OM treated patients' doudenal biopsies as in celiac by staining anti-CD8, anti-CD4, anti-IL-15R, anti-ZO-1, anti-FoxP3, anti-psmad 2/3 [59][60][61][62]. Marthey et al. determined that OM causes severe enteropathy with or without 
villous atrophy in national survey of France. Intraepithelial lymphocytes increase (IELs] was recorded in many OM celiac-like cases [63]. Severe chronic diarrhea, electrolyte imbalance, acute renal failure and significant weight loss were observed in some cases [64]. Burbure et al. have recently examined all studies about OM enteropathy and described its histopathologic differential diagnosis in his detailed study [65]. In all of these cases, clinical symptoms improved and histological changes disappeared after cessation of OM treatment [66]. According to Burbure's study, the histopathological features of celiac disease are intraepithelial lymphocytosis, crypt hyperplasia and villous atrophy. The distinctive features of ARB-enteropathy from celiac are sometimes IEL and frequent accumulation of collagen within or near normal limits. Similarly Lagana reported that duodenal injury was associated with the use of OM [58]. The duodenal biopsy results revealed the villous atrophy and enteropathy like celiac in antitissue transglutaminase (TTG) antibody negative patient taking OM [67]. De Gateni found villous atrophy associated with OM use [68]. Although there are many case reports about this side effect, these studies represent only a certain part of the relevant cases. Many other medications except OM like mycophenolic acid, azathioprine, methotrexate, neomycin, and colchicine can cause diarrhea by increasing motility, inflammation or enteropathy and damage to the intestinal villi leading to chronic diarrhea [69][70]. A recent article based on 4546680 patients in the French National Health Insurance database evaluated the risk of intestinal malabsorption associated with OM, other ARBs and ACEI. When compared with other ACEI, OM is associated with intestinal malabsorption and celiac disease [71]. Case reports of patients taking other angiotensin receptor blockers (valsartan, irbesartan, telmisartan, eprosartan, losartan, and candesartan) demonstrating a profound celiac-like enteropathy findings and villous atrophy are also exist and mentioned above [72][44][73][50][49][72][74][41][53][54].
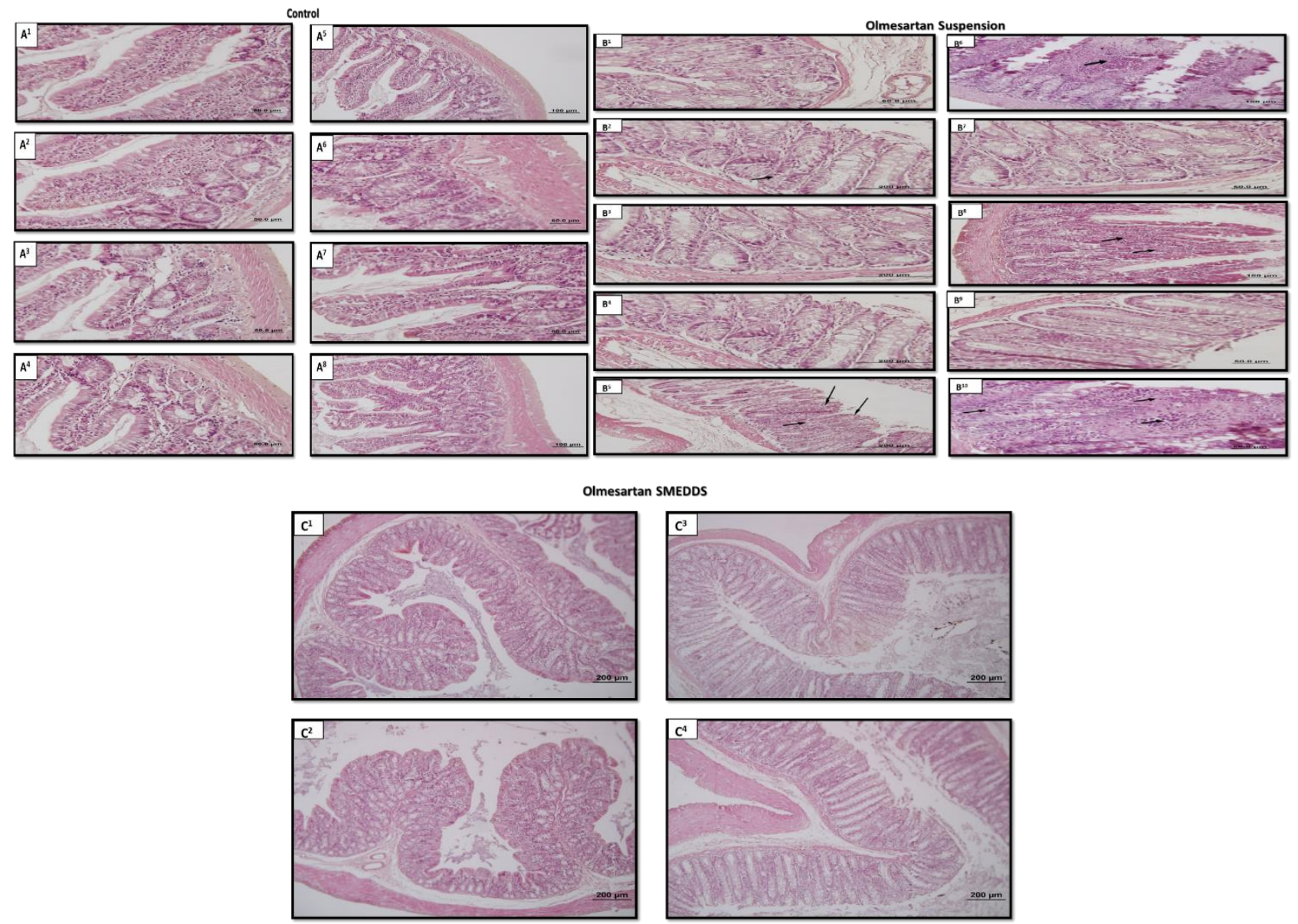

Figure 2. Images of histopathological examinations in rat duodenum after treatment with OM-SMEDDS or OM-Suspension. Formulation of OM-SMEDDS administered (C1, C2, C3, C4) and control group (A1, A2, A3, A4, A5, A6, A7, A8) intestinal imaging did not indicate enteropathy findings like celiac in contrast to the OM-Suspension administered rats. Duodenum biopsy showed Olmesartan-associated enteropathy findings, intense mononuclear cell infiltration and villous atrophy in OM-Suspension administered group of rats. Arrows indicates increased mononuclear cell infiltration (B1, B2, B3, B4, B5, B6, B7, B8, B9, B10). Scale was $50 \mu \mathrm{m}, 100 \mu \mathrm{m}$ and $200 \mu \mathrm{m}$. 
Mechanisms during the passage of drugs through the intestinal mucosa; and the activity of the drug is related to the interaction between the drug carrier and the biological environment. In our current study, OMSMEDDS improved the bioavailability, solubility and absorption of the drug by incorporating and encapsulating of the hydrophobic active ingredient into the oil phase, and unlike suspension, it did not harm the intestinal histology. But OM-Suspension directly interacted with intestinal mucosa and caused celiac-like enteropathy. Carboxymethylenebutenolidase (CMBL), human plasma paraoxonase (PON1) enzymes and plasma albumin are responsible for hydrolyzing prodrug olmesartan medoxomil to olmesartan and its bioactivation [75][76][77][78]. They are also responsible for the disintegration of gluten and gliadin peptides in the intestines. Therefore, excessive consumption of these enzymes involved in the hydrolysis of olmesartan caused severe diarrhea and celiac-like enteropathy [79][80][81][78][82][83]. Celiac disease is associated with oxidative damage and with significant decrease of PON1 activities [84]. The intestinal T cell response to agliadine in adult celiac patients is related with two immunodominant epitopes, PFPQPQLPY and PQPQLPYPQ. These epitopes are responsible for the primary inflammatory response. They are exceptionally resistant to enzymatic processing. Two brush border membrane (BBM) peptidases, dipeptidyl peptidase IV (DPP IV) and dipeptidyl carboxypeptidase I (DCP I, also known as angiotensin- converting enzyme or peptidyl dipeptidase A) are rate limiting in their digestive breakdown. Supplementation of the BBM with bacterial prolyl endopeptidase (PEP) leads to rapid cleavage of these gliadin peptides to units much smaller than the binding site of the HLA molecules. This suggests a possible enzyme supplement therapy for celiac sprue [85]. In our study, intense mononuclear cell infiltration, villous atrophy, weight loss and diarrhea were observed in the OM-Suspension administered rat group at the end of the one-month period [81][78][40][47]. Our olmesartan-induced celiac- rat- model findings supported clinical findings in this field. OM as a nonvitamin D VDR ligand also restores VDR capability and activates the immune system and reduces inflammatory symptoms. This phenomenon also explains our rats intestinal findings in terms of immune response. [28][3][86][87]. There are also many clinical studies showing that ACE2-enhancing ACEIs/ARBs used by patients with hypertension can be safely used in patients with COVID 19 [88][89][90][91][92][93][94]. ARBs increase Ang II activity on AT2R by blocking AT1R. This situation affects the conversion of Ang II to other RAS mediators such as Ang (1-7) by ACE2 acting on the Mas receptor [95]. Endogenous Ang II induces inflammation process and plays a key role in the immunomodulation of $\mathrm{T}$ cell responses such as activation and posterior adhesion/transmigration activity. Hence, the use of AngII/AT1 signal antagonists in therapeutic strategies to improve treatment outcomes of immune-based diseases is feasible [96]. ACE2-raising drugs increase ACE2 activity and cause anti-inflammatory, anti-fibrotic and anti-oxidative effects by ACE2Ang-(1-7)-MasR pathway in COVID 19 patients [1]. It is reported that OM and candesartan attenuate the development of heart failure after experimental autoimmune myocarditis in rats by modulation of the ANG 1-7 mas receptor [97][98]. The importance of RAS blockade are also expressed in diabetic complications such as cardiomyopathy, nephropathy, and neuropathy [95][99]. ACE2, an ACE-related carboxypeptidase, hydrolyzes Ang I to Ang-(1-9) and Ang II to Ang-(1-7). OM increases plasma Ang-(1-7) through an increase in ACE2 expression in rats with myocardial infarction. This over-expression of ACE2 is related to a reduction in Ang II level and the cardioprotective effect of OM [100]. Quantification of immunostaining in the thoracic aorta for both ACE2 and ANG- (1-7) antibodies showed higher intensity in spontaneously hypertensive rats treated with OM as a manifestation of enhanced anti-inflammatory effect of OM in tissues [101]. ACEIs / ARBs have beneficial effects, such as lowering the risk of mortality in hypertensive patients or reducing the risk of hospitalization for COVID-19 patients with diabetes. The increased ACE2 activity causes the balance within the RAAS to shift towards the ACE2-Ang- (1-7) -MasR pathway. Anti-inflammatory effects of the ACE2-Ang1-7-MasR pathway may explain the increased survival of COVID-19 patients using ACEI/ARBs in hypertension. [1] In another study supporting this data is Ang- (1-7) nanocarriers inhalation has been shown to induce anti-inflammatory effects and attenuated pulmonary remodeling in a mice model of allergic lung inflammation [102]. Ang (1-7) acts on Mas receptor causing vasodilatation and protects from adverse remodeling of heart and kidney. Kuba et al. reported that the RAS has a crucial role in severe acute lung injury and that the SARS-CoV receptor ACE2 has a protective role in acute lung failure. SARS-CoV Spike-mediated lung failure can be rescued by inhibition of AT1R. ACE2, a carboxypeptidase, generates Ang1-7 from angiotensin I and Ang1-9 from angiotensin II. [103][104]. VDR agonists are immunoregulators and modulate tolerogenic properties in blood myeloid but not plasmacytoid DCs [105]. In view of these data, activation of ACE2-Ang- (1-7) pathway by exogenous application of Ang- (1-7) or ACE2 or its activators would be therapeutically beneficial for immunomodulator effects. For example it has been stated anti-inflammatory agent dexamethasone is useful in the management of COVID-19 [106]. But it is also known that chronic 
administration of dexamethasone reduces ACE2 levels, increases the risk of infection and plasma viral load, reduces immune function, and prevents antibody production with its immunosuppressant effect [107][108]. The high concentrations of olmesartan activates the VDR at an effective level for the activation of the innate immune response. In this case, designing drugs of ACE2-raising ACEIs/ARBs targeted for the immun diseases will be useful [102].

\section{CONCLUSION}

In this study various effect mechanisms of $\mathrm{OM}$ and its possible effectiveness in immune system diseases were discussed. Our histopathological findings of olmesartan-induced celiac-like enteropathy in rat intestines were increased mononuclear cell infiltration and villous atrophy. Hydrolysing mecanishm of olmesartan medoxomil by the enzymes like paraoxonases and carboxymethylenebutenolidase and carboxylesterase are responsible for the celiac like entetropathy. Since the same enzymes are involved in the breakdown of gliadine, long-term OM exposure causes side effects similar to celiac disease. The mechanism of intestinal injury of OM is also thought to be a cell-mediated immune response and genetic predisposition. This severe enteropathy may also be due to the different affinity of OM on a VDR, PPAR and CCR2b receptors that can modulate the immune system. Our findings of OM-Suspension exposure in rat intestines supported and correlated clinical findings of OM's celiac like enteropathy effect. But our designed OM-SMEDDS formulation did not show any enteropathy findings in the intestines. This effect was only due to the exposure of the unencapsulated pure $\mathrm{OM}$ in the suspension with the intestines. We proved that OM does not cause enteropathy in the intestines when encapsulated with proper lipid nano drug delivery systems specific to its solubility properties. Hence, this is a manifestation of the enteropathy adverse effect of $\mathrm{OM}$ is only due to local intense exposure with the hydrolising enzymes in the intestines. VDR stimulation can also be effective on severe inflammation findings in some cases. The combination of RAS blockade and VDR stimulation appears to be more effective than each one used individually. Considering VDR agonist immunogenic, ACE2-Ang-(1-7)-MasR pathway activating and ACE2-raising activities of OM it should take place as a curing agent in immun system diseases. As a nonvitamin D VDR ligand (an angiotensin receptor blocker) OM reactivates the immune system, restores VDR competence, corrects dysregulated vitamin D metabolism and reduce inflammatory symptoms. Therefore immune modulatory therapies that enhance VDR expression and activity should be considered in the clinical setting of immun diseases. In conclusion, by performing extensive evaluations, $\mathrm{OM}$ can be a promising immunotherapeutic and healing agent in immune diseases.

\section{MATERIALS AND METHODS}

\subsection{Materials}

Tween 80 was purchased from Merck, USA. Transcutol was granted Gattefosse, France, OM was supplied from Alembic Pharmaceuticals Gujarat, India. Span 80, Oleic acid were obtained from Sigma-Aldrich, Germany. All chemicals, reagents and solvents used in the studies were analytical grade.

\subsection{Animals}

Histological studies were performed on albino 18 male normotensive Wistar Rats (160-180 g). The Animals were purchased from the Central Animal Laboratory of Ege University (Izmir, Turkey) and were kept in complying with the NIH guidelines. Animals were kept polypropylene cage which is at $25 \pm 2{ }^{\circ} \mathrm{C}$ and $55 \pm 5 \% \mathrm{RH}$. They had freely accessed to standard diet and water, in $12 \mathrm{~h}$ light/dark cycle. All animal experiments were examined by the Ethics Committee of Ege University. The assay protocol was confirmed by the Ethics Committee Report of Ege University Animal Experiments, Permit Issue: 2014-073/25.02.2015

\subsection{Preparation of OM-SMEDDS and OM-suspension}

The experiments were carried out using our previous standardized and optimized Self microemulsifying drug delivery system (SMEDDS) with $150 \mathrm{~nm}$ droplet size and validated HPLC method that reported in our previous article (Komesli et al. 2019). The formulation contains $14.72 \%$ Oleic acid as oil, $16.218 \%$ Tween 80 and $16.218 \%$ Span 80 as surfactant, $32.435 \%$ Transcutol as co-surfactant and $20.41 \%$ water and $\mathrm{OM}$ as an active ingredient. The OM-SMEDDS was formulated at a dose of $1 \mathrm{mg} / \mathrm{ml}$ in accordance with the physicochemical properties of OM by the technique of our previous publication [109]. The OM-Suspension was obtained by suspending $0.25 \mathrm{~g}$ of CMC in $100 \mathrm{~mL}$ distilled water and adding $1 \mathrm{mg} / \mathrm{ml}$ of the active ingredient. 


\subsection{Administration of drug formulations}

Rats were designed in three groups $(n=6)$. Group 1 was defined as the control group and drug was not given. Group 2 rats received a treatment at a dose of $1.3 \mathrm{mg} / \mathrm{kg}$ OM-SMEDDS and Group 3 rats received a dose of $1.3 \mathrm{mg} / \mathrm{kg}$ OM-Suspension orally once a day for a month. The dose administered was determined by considering the pharmacokinetic parameters in earlier publications and the equation 1 based on body surface area below. The OM treatment was continued for one month and the histopathological effects of formulations were analysed [15][42][43]

Animal dose $(\mathrm{mg} / \mathrm{kg})=$ human equivalent dose $(\mathrm{mg} / \mathrm{kg}) \times$ humanKm/animalKm

$\mathrm{Km}=$ the surface area to weight ratios.

\subsection{Histopatological examinations}

After 1 month exposure to OM, the duodenal part of the intestinal samples were taken from the OMSMEDDS, OM-Suspension-treated groups and the control group. Results were evaluated and compared histologically for celiac-like enteropathy. Histochemical examinations were made by fixing intestinal epithelial samples with $10 \%$ formol and taking sections. Samples were washed overnight under flow to remove the fixative and kept for 20 minutes in 70\%, 80\% and 96\% ethyl alcohol and 4 different batches of acetone for dehydration, respectively. Subjected to 2 different xylenes for 30 minutes for transparency. The samples were embedded in hard paraffin after being dipped in soft paraffin 2 times, for 1 hour each. The samples were microtomized with a 5 micrometer thick rotary microtome (RM2255, Leica) [110].

\subsection{Hematoxylin eosin protocol}

Sections were kept overnight in a $60^{\circ} \mathrm{C}$ incubator for deparaffinization. They were exposed to three different xylenes for 20 minutes (in the oven) and twice for 10 minutes. Five different decreasing alcohol ratios were used for dehydration. The sections were rinsed with distilled water and stained with hematoxylin (01562E, Surgipath, Bretton, Peter Borough, Cambridgeshire) for 10 minutes. Sections were washed in a stream for 10 minutes to remove excess dye from tissue. It was then stained with Eosin (01602E, Surgipath, Bretton, Peter Borough, Cambridgeshire) for 2 minutes. Sections were passed through 2 series of absolute alcohol, $70 \%$, $80 \%, 96 \%$, respectively, and kept in three different xylenes to ensure 20 minutes transparency. Sections were closed with main compartments (UN 1866, Merck, Darmstadt, Germany). After staining, intestinal histopathology was visualized by electron microscopy. OM-SMEDDS, OM-Suspension, and control group images were evaluated for the presence of celiac-like enteropathy at one month.

Acknowledgements: The authors acknowledge to Aliye Uster Foundation and ARGEFAR Pre-phase Research Unit, Laboratory of Experimental Animals, Ege University (Izmir, Turkey) for providing support. They also acknowledge Prof. Dr. Bekir Ugur Ergur for his great supports in histology field.

Author contributions: Concept - E.K.; Design - E.K.; Supervision - E.K.; Resources - E.K.; Materials - Y.K.; Data Collection and/or Processing - Y.K.; Analysis and/or Interpretation - Y.K.; Literature Search - Y.K.; Writing - Y.K.; Critical Reviews - E.K, Y.K.

Conflict of interest statement: No potential conflict of interest was reported by the authors.

Ethics committee approval: The animal assay protocol was confirmed by the Ethics Committee Report of Ege University Animal Experiments, Permit Issue: 2014-073/25.02.2015.

Funding: The author acknowledges to Aliye Uster Foundation for funding of this study. This work was also supported by the Ege University Scientific Research Project Commission (BAP), Izmir-Turkey, Grant Number 15-ECZ-014.

\section{REFERENCES}

[1] Akhtar S, Benter IF, Danjuma MI, Doi SAR, Hasan SS, Habib AM. Pharmacotherapy in COVID-19 patients: a review of ACE2-raising drugs and their clinical safety. J Drug Target. 2020; 28(7-8): 683-699. [CrossRef]

[2] Sacristán D, Marquesz M, Zamorano-León JJ, Luque M, Armengol J, del Castillo J. Modifications by Olmesartan medoxomil treatment of the platelet protein profile of moderate hypertensive patients. Proteomics - Clin Appl. 2008; 


\section{2(9): 1300-1312. [CrossRef]}

[3 ] Mangin M, Sinha R, Fincher K. Inflammation and vitamin D: the infection connection. Inflamm Res. $2014 ; 63$ (10): 803-819. [CrossRef]

[4] Li YC, Kong J, Wei M, Chen ZF, Liu SQ, Cao LP. 1,25-Dihydroxyvitamin D3 is a negative endocrine regulator of the renin-angiotensin system. J Clin Invest. 2002; 110(2): 229-238. [CrossRef]

[5] Suzuki Y, Ruiz-Ortega M, Lorenzo O, Ruperez M, Esteban V, Egido J. Inflammation and angiotensin II. Int J Biochem Cell Biol. 2003; 35(6): 881-900. [CrossRef]

[6] Ferder M, Inserra F, Manucha W, Ferder L. The world pandemic of vitamin D deficiency could possibly be explained by cellular inflammatory response activity induced by the renin-angiotensin system. Am J Physiol - Cell Physiol. 2013; 304(11): 1027-1039. [CrossRef]

[7] Talbot G H, Small bowel histopathologic findings suggestive of celiac disease in an asymptomatic patient receiving olmesartan. Mayo Clin Proc. 2012; 87(12): 1231-1232. [CrossRef]

[8] Fummi C. Severe enteropathy induced by olmesartan: a case report. Fundam Clin Pharmacol. 2014; (28): 91-114. [CrossRef]

[9] Papista C, Gerakopoulos V, Kourelis A, Sounidaki M, Kontana A, Berthelot L. Gluten induces coeliac-like disease in sensitised mice involving IgA, CD71 and transglutaminase 2 interactions that are prevented by probiotics. Lab Investig. 2012; 92(4): 625-635. [CrossRef]

[10] Kaswala D, Veeraraghavan G, Kelly C, Leffler D. Celiac Disease: Diagnostic Standards and Dilemmas. Diseases. 2015; 3(2): 86-101. [CrossRef]

[11] Oberhuber G. Histopathology of celiac disease. Biomed Pharmacother. 2000; 54(7): 368-372. [CrossRef]

[12] Niewinski MM. Advances in Celiac Disease and Gluten-Free Diet. J Am Diet Assoc. 2008; 108 (4): 661-672. [CrossRef]

[13] Garrote JA, Gómez-González E, Bernardo D, Arranz E, Chirdo F. Celiac disease pathogenesis: the proinflammatory cytokine network. J Pediatr Gastroenterol Nutr. 2008; 47(Suppl 1): S27-32. [CrossRef]

[14] Kagnoff MF. Celiac disease: Pathogenesis of a model immunogenetic disease. J Clin Invest. 2007; 117(1): 41-49 [CrossRef]

[15] Gorain B, Choudhury H, Kundu A, Sarkar L, Karmakar S, Jaisankar P, et al. Nanoemulsion strategy for olmesartan medoxomil improves oral absorption and extended antihypertensive activity in hypertensive rats. Colloids Surf B Biointerfaces. 2014; 115: 286-294. [CrossRef]

[16] Mulllertz A, Ogbonna A, Ren S, Rades T. New perspectives on lipid and surfactant based drug delivery systems for oral delivery of poorly soluble drugs. J Pharm Pharmacol. 2010; 62: 1622-1636. [CrossRef]

[17] Fatouros DG, Bergenstahl B, Mullertz A. Morphological observations on a lipid-based drug delivery system during in vitro digestion. Eur J Pharm Sci. 2007; 31(2): 85-94 [CrossRef]

[18] Marshall TG, Lee RE, Marshall FE. Common angiotensin receptor blockers may directly modulate the immune system via VDR, PPAR and CCR2b. Theor Biol Med Model. 2006; 3: 1. [CrossRef]

[19] Jones G, Prosser DE, Kaufmann M. 25-Hydroxyvitamin D-24-hydroxylase (CYP24A1): Its important role in the degradation of vitamin D. Arch Biochem Biophys. 2012; 523(1): 9-18. [CrossRef]

[20] Kongsbak M, Levring TB, Geisler C, von Essen MR. The vitamin D receptor and T cell function. Front Immunol. 2013; 4(18): 1-10. [CrossRef]

[21] Arao T, Okada Y, Mori H, Nishida K, Tanaka Y. Antihypertensive and metabolic effects of high-dose olmesartan and telmisartan in type 2 diabetes patients with hypertension. Endocr J. 2013; 60(5): 563-570. [CrossRef]

[22] Fliser D, Buchholz K, Haller H. Antiinflammatory effects of angiotensin II subtype 1 receptor blockade in hypertensive patients with microinflammation. Circulation. 2004; 110(9): 1103-1107. [CrossRef]

[23] Platten M, Youssef S, Eun MH, Ho PP, Han MH, Lanz T V. Blocking angiotensin-converting enzyme induces potent regulatory T cells and modulates TH1- and TH17-mediated autoimmunity. Proc Natl Acad Sci U S A. 2009; 106(35): 14948-14953. [CrossRef]

[24] Izu Y, Mizoguchi F, Kawamata A, Hayata T, Nakamoto T, Nakashima K, et al. Angiotensin II type 2 receptor blockade increases bone mass. J Biol Chem. 2009; 284(8): 4857-4864. [CrossRef]

[25] Shimizu H, Nakagami H, Osako MK, Hanayama R, Kunugiza Y, Kizawa T, et al. Angiotensin II accelerates osteoporosis by activating osteoclasts. FASEB J. 2008; 22(7): 2465-2475. [CrossRef] 
[26] Li YC, Kong J, Wei M, Chen Z-F, Liu SQ, Cao L-P. 1,25-Dihydroxyvitamin D3 is a negative endocrine regulator of the renin-angiotensin system. J Clin Invest. 2002; 110(2): 229-238. [CrossRef]

[27] Belum GR, Belum VR, Chaitanya Arudra SK, Reddy BSN. The Jarisch-Herxheimer reaction: Revisited. Travel Med Infect Dis. 2013; 11(4): 231-237. [CrossRef]

[28] Hurley JC. Antibiotic-Induced Release of Endotoxin A Therapeutic Paradox. Drug Saf. $1995 ; 12$ (3): $183-195$. [CrossRef]

[29] Sonawane A, Santos JC, Mishra BB, Jena P, Progida C, Sorensen OE. Cathelicidin is involved in the intracellular killing of mycobacteria in macrophages. Cell Microbiol. 2011; 13(10): 1601-1617. [CrossRef]

[30] Nickel D, Busch M, Mayer D, Hagemann B, Knoll V, Stenger S. Hypoxia Triggers the Expression of Human $\beta$ Defensin 2 and Antimicrobial Activity against Mycobacterium tuberculosis in Human Macrophages . J Immunol. 2012; 188(8): 4001-4007. [CrossRef]

[31] Hajishengallis G, Lambris JD. Microbial manipulation of receptor crosstalk in innate immunity. Nat Rev Immunol. 2011; 11(3): 187-200. [CrossRef]

[32] Takizawa S, Dan T, Uesugi T, Nagata E, Takagi S, Van Ypersele De Strihou C, et al. A sartan derivative with a very low angiotensin II receptor affinity ameliorates ischemic cerebral damage. J Cereb Blood Flow Metab. 2009; 29(10): 1665-1672. [CrossRef]

[33] Ferrario C. Effect of angiotensin receptor blockade on endothelial function: Focus on olmesartan medoxomil. Vasc Health Risk Manag. 2009; 5(1): 301-314. [CrossRef]

[34] Schwocho LR, Masonson HN. Pharmacokinetics of CS-866, a new angiotensin II receptor blocker, in healthy subjects. J Clin Pharmacol. 2001; 41(5): 515-527. [CrossRef]

[35] Proal AD, Albert PJ, Marshall TG, Blaney GP, Lindseth IA. Immunostimulation in the treatment for chronic fatigue syndrome/myalgic encephalomyelitis. Immunol Res. 2013; 56(2-3): 398-412. [CrossRef]

[36] Waterhouse JC, Perez TH, Albert PJ. Reversing bacteria-induced vitamin D receptor dysfunction is key to autoimmune disease. In: Annals of the New York Academy of Sciences. 2009; 1173: 757-765. [CrossRef]

[37] Lemire J. 1,25-Dihydroxyvitamin D3- a hormone with immunomodulatory properties1,25-Dihydroxyvitamin D3ein Hormon mit immunmodulierenden Eigenschaften. Z Rheumatol. 2000; 59(Suppl 1): 24-27. [CrossRef]

[38] Zhang Y, Leung DYM, Richers BN, Liu Y, Remigio LK, Riches DW, et al. Vitamin D Inhibits Monocyte/Macrophage Proinflammatory Cytokine Production by Targeting MAPK Phosphatase-1. J Immunol. 2012; 188(5): $2127-2135$. [CrossRef]

[39] Arnson Y, Amital H, Shoenfeld Y. Vitamin D and autoimmunity: New aetiological and therapeutic considerations. Ann Rheum Dis. 2007; 66(9): 1137-1142. [CrossRef]

[40] Marietta EV, Cartee A, Rishi A, Murray JA. Drug-induced enteropathy. Dig Dis. 2015; 33(2): 215-220. [CrossRef]

[41] Malfertheiner P, Ripellino C, Cataldo N. Severe intestinal malabsorption associated with ACE inhibitor or angiotensin receptor blocker treatment. An observational cohort study in Germany and Italy. Pharmacoepidemiol Drug Saf. 2018; 27(6): 581-586. [CrossRef]

[42] Mizuno M, Sada T, Kato M, Korke H. Renoprotective Effects of Blockade of Angiotensin II AT1 Receptors in an Animal Model of Type 2 Diabetes. Hypertens Res. 2002; 25(2): 271-278. [CrossRef]

[43] Reagan-Shaw S, Nihal M, Ahmad N. Dose translation from animal to human studies revisited. FASEB J. 2008; 22(3): 659-661. [CrossRef]

[44] Zanelli M. Sprue-like enteropathy associated with angiotensin ii receptor blockers other than olmesartan. Aliment Pharmacol Ther. 2017; 46(4): 471-473. [CrossRef]

[45] Marsh MN. Gluten, major histocompatibility complex, and the small intestine. Gastroenterology. 2016; 102(1): 330354. [CrossRef]

[46] Husby S, Koletzko S, Korponay-Szabó IR, Mearin ML, Phillips A, Shamir R, et al. European society for pediatric gastroenterology, hepatology, and nutrition guidelines for the diagnosis of coeliac disease. J Pediatr Gastroenterol Nutr. 2012; 54(1): 136-160. [CrossRef]

[47] Esteve M, Temiño R, Carrasco A, Batista L, Del Val A, Blé M, et al. Potential coeliac disease markers and autoimmunity in olmesartan induced enteropathy: A population-based study. Dig Liver Dis. 2016; 48(2): $154-161$. [CrossRef]

[48] Kourlaba G, Gialama F, Tsioufis K, Maniadakis N. A literature review to evaluate the clinical and economic value of 
olmesartan for the treatment of hypertensive patients. Int J Cardiol. 2016; 221(15): 60-74. [CrossRef]

[49] Marthey L, Cadiot G, Seksik P, Pouderoux P, Lacroute J, Skinazi F, et al. Olmesartan-associated enteropathy: Results of a national survey. Aliment Pharmacol Ther. 2014; 40(9): 1103-1109. [CrossRef]

[50] Mendoza P. Enteropathy related to angiotensin II receptor antagonist losartan: Case study. Clin Transl Allergy. 2016; 6(Suppl 3): 92-101. [CrossRef]

[51] Hoegh-Petersen M, Thomsen AR, Christensen JP, Holst PJ. Mucosal immunization with recombinant adenoviral vectors expressing murine gammaherpesvirus-68 genes M2 and M3 can reduce latent viral load. Vaccine. 2009; 27(48): 6723-6730. [CrossRef]

[52] Dreifuss SE, Tomizawa Y, Farber NJ, Davison JM, Sohnen AE. Spruelike Enteropathy Associated with Olmesartan: An Unusual Case of Severe Diarrhea. Case Rep Gastrointest Med. 2013; 618071: 1-3. [CrossRef]

[53] Cyrany J, Vasatko T, Machac J, Nova M, Szanyi J, Kopacova M. Letter: Telmisartan-associated enteropathy - Is there any class effect? Aliment Pharmacol Ther. 2014; 40(5): 569-570. [CrossRef]

[54] Mandavdhare HS, Sharma V, Prasad KK, Kumar A, Rathi M, Rana SS. Telmisartan-induced sprue-like enteropathy: A case report and a review of patients using non-olmesartan angiotensin receptor blockers. Intest Res. 2017; 15(3): 419-421. [CrossRef]

[55] Maier H, Hehemann K, Vieth M. Celiac disease-like enteropathy due to antihypertensive therapy with the angiotensin-II receptor type 1 inhibitor eprosartan. Cesk Patol. 2015; 51(2): 87-88. [CrossRef]

[56] Khan AS, Peter S, Wilcox CM. Olmesartan-induced enteropathy resembling celiac disease. Endoscopy. 2014; 46: E97E98. [CrossRef]

[57] Carneiro L, Moreira A, Pereira A, Andrade C, Soares J, Silva A. Olmesartan-Induced Sprue Like Enteropathy. GE Port J Gastroenterol. 2016; 23(2): 101-105. [CrossRef]

[58] Lagana SM, Braunstein ED, Arguelles-Grande C, Bhagat G, Green PHR, Lebwohl B. Sprue-Like histology in patients with abdominal pain taking olmesartan compared with other angiotensin receptor blockers. J Clin Pathol. 2015; 68(1): 29-32. [CrossRef]

[59] Yadav AA, Yadav DS, Karekar PS, Pore Y V, Gajare P. Enhanced solubility and dissolution rate of Olmesartan medoxomil using crystallo-co-agglomeration technique. Pelagia Res Libr. 2012; 3(2): 160-169. [CrossRef]

[60] Pallav K, Leffler DA, Tariq S, Kabbani T, Hansen J, Peer A, et al. Noncoeliac enteropathy: The differential diagnosis of villous atrophy in contemporary clinical practice. Aliment Pharmacol Ther. 2012; 35(3): 380-390. [CrossRef]

[61] Seth A, Gupta V, Jain P. Olmesartan: An overlooked cause for non-celiac sprue like enteropathy. Asian J Pharm Pharmacol. 2018; 4(1): 83-86. [CrossRef]

[62] Marietta E V, Nadeau AM, Cartee AK, Singh I, Rishi A, Choung RS, et al. Immunopathogenesis of olmesartanassociated enteropathy. Aliment Pharmacol Ther. 2015; 42(11-12): 1303-1314. [CrossRef]

[63] Bhat N, Anupama NK, Yelsangikar A, Vizhi K. Olmesartan-related sprue-like enteropathy. Indian J Gastroenterol. 2014; 33(6): 564-567. [CrossRef]

[64] Martins C, Teixeira C, Ribeiro S, Trabulo D, Cardoso C, Mangualde J, et al. Seronegative Intestinal Villous Atrophy: A Diagnostic Challenge. Case Rep Gastrointest Med. 2016; 6392028: 1-4. [CrossRef]

[65] Burbure N, Lebwohl B, Arguelles-Grande C, Green PHR, Bhagat G, Lagana S. Olmesartan-associated sprue-like enteropathy: A systematic review with emphasis on histopathology. Hum Pathol. 2016; 50: 127-134. [CrossRef]

[66] Scialom S, Malamut G, Meresse B, Guegan N, Brousse N, Verkarre V, et al. Gastrointestinal disorder associated with olmesartan mimics autoimmune enteropathy. PLoS One. 2015; 10(6): e0125024. [CrossRef]

[67] Kulai T, Arnason T, MacIntosh D, Igoe J. Duodenal Villous Atrophy in a TTG-Negative Patient Taking Olmesartan: A Case Report and Review of the Literature. Can J Gastroenterol Hepatol. 2016; 6091571. [CrossRef]

[68] Negro A, Rossi GM, Santi R, Iori V, De Marco L. A Case of Severe Sprue-like Enteropathy Associated with Losartan. J Clin Gastroenterol. 2015; 49(9): 794. [CrossRef]

[69] Hickson J, Ackler S, Klaubert D, Bouska J, Ellis P, Foster K, Oleksijew A, Rodriguez L, Schlessinger S, Wang B, Frost $\mathrm{D}$, et al. Noninvasive molecular imaging of apoptosis in vivo using a modified firefly luciferase substrate, Z-DEVDaminoluciferin. Cell Death Differ. 2010; 17(6): 1003-1010. [CrossRef]

[70] Tran TH, Li H. Olmesartan and drug-induced enteropathy. P T a peer-reviewed J Formul Manag a peer-reviewed J Formul Manag. 2014; 39(1): 47-50. [CrossRef] 
[71] Basson M, Mezzarobba M, Weill A, Ricordeau P, Allemand H, Alla F, et al. Severe intestinal malabsorption associated with olmesartan: A French nationwide observational cohort study. Gut. 2015; 65(10): 1664-1669. [CrossRef]

[72] Hehemann K, Vieth M, Maier H. Celiac disease-like enteropathy due to antihypertensive therapy with the angiotensin-II receptor type 1 inhibitor eprosartan. Cesk Patol. 2015; 51(2): 87-88. [CrossRef]

[73] Herman ML, Rubio-Tapia A, Wu TT, Murray JA. A case of severe sprue-like enteropathy associated with valsartan. ACG Case Reports J. 2015; 2(2): 92-94. [CrossRef]

[74] Mondet L. Angiotensin II receptor blockers-induced enteropathy: Not just olmesartan! A case report with candesartan. Fundam Clin Pharmacol. 2016, 30(Suppl. 1): 47-87. [CrossRef]

[75] Précourt LP, Marcil V, Ntimbane T, Taha R, Lavoie JC, Delvin E, et al. Antioxidative properties of paraoxonase 2 in intestinal epithelial cells. Am J Physiol - Gastrointest Liver Physiol. 2012; 303: G623-G634. [CrossRef]

[76] Laeis P, Puchler K, Kirch W. The pharmacokinetic and metabolic profile of olmesartan medoxomil limits the risk of clinically relevant drug interaction. J Hypertens Suppl. 2001; 19(1): S21-32. [CrossRef]

[77] Ma SF, Anraku M, Iwao Y, Yamasaki K, Kragh-Hansen U, Yamaotsu N, et al. Hydrolysis of angiotensin II receptor blocker prodrug olmesartan medoxomil by human serum albumin and identification of its catalytic active sites. Drug Metab Dispos. 2005; 33(12): 1911-1919. [CrossRef]

[78] Nishimuta H, Houston JB, Galetin A. Hepatic, intestinal, renal, and plasma hydrolysis of prodrugs in human, cynomolgus monkey, dog, and rat: Implications for in vitro-in vivo extrapolation of clearance of prodrugs. Drug Metab Dispos. 2014; 42(9): 1522-1531. [CrossRef]

[79] Ishizuka T, Yoshigae Y, Murayama N, Izumi T. Different hydrolases involved in bioactivation of prodrug-type angiotensin receptor blockers: Carboxymethylenebutenolidase and carboxylesterase 1. Drug Metab Dispos. 2013; 41(11): 1888-1895. [CrossRef]

[80] Ishizuka T, Fujimori I, Nishida A, Sakurai H, Yoshigae Y, Nakahara K, et al. Paraoxonase 1 as a major bioactivating hydrolase for olmesartan medoxomil in human blood circulation: Molecular identification and contribution to plasma metabolism. Drug Metab Dispos. 2012; 40(2):374-380. [CrossRef]

[81] Furlong CE, Marsillach J, Jarvik GP, Costa LG. Paraoxonases-1, -2 and -3: What are their Functions? Chem Biol Interact. 2016; 259(PtB): 51-62. [CrossRef]

[82] Ishizuka T, Fujimori I, Kato M, Noji-Sakikawa C, Saito M, Yoshigae Y, et al. Human carboxymethylenebutenolidase as a bioactivating hydrolase of olmesartan medoxomil in liver and intestine. J Biol Chem. 2010; 285 (16): $11892-11902$. [CrossRef]

[83] Ishizuka T, Rozehnal V, Fischer T, Kato A, Endo S, Yoshigae $\mathrm{Y}$, et al. Interindividual variability of carboxymethylenebutenolidase homolog, a novel olmesartan medoxomil hydrolase, in the human liver and intestines. Drug Metab Dispos. 2013; 41(5): 1156-1162. [CrossRef]

[84] Ferretti G, Bacchetti T, Saturni L, Manzella N, Candelaresi C, Benedetti A, et al. Lipid Peroxidation and Paraoxonase1 Activity in Celiac Disease. J Lipids. 2012; 587479. [CrossRef]

[85] Hausch F, Shan L, Santiago NA, Gray GM, Khosla C. Intestinal digestive resistance of immunodominant gliadin peptides. Am J Physiol - Gastrointest Liver Physiol. 2002; 283(4): G996-G1003. [CrossRef]

[86] Woolard MD, Frelinger JA. Outsmarting the host: Bacteria modulating the immune response. Immunol Res. 2008; 41(3): 188-202. [CrossRef]

[87] Dermine JF, Desjardins M. Survival of intracellular pathogens within macrophages. Protoplasma. 1999; $210: 11-24$. [CrossRef]

[88] Smith GR. Angiotensin and systems thinking: Wrapping your mind around the big picture. Ochsner J. 2013; 13(1): 11-25. [CrossRef]

[89] Reynolds HR, Adhikari S, Pulgarin C, Troxel AB, Iturrate E, Johnson SB, et al. Renin-Angiotensin-Aldosterone System Inhibitors and Risk of Covid-19. N Engl J Med. 2020; 382(25): 2441-2448. [CrossRef]

[90] Yang G, Tan Z, Zhou L, Yang M, Peng L, Liu J, et al. Effects Of ARBs And ACEIs On Virus Infection, Inflammatory Status And Clinical Outcomes In COVID-19 Patients With Hypertension: A Single Center Retrospective Study. Hypertens. 2020; 76(1): 51-58. [CrossRef]

[91] Li J, Wang X, Chen J, Zhang H, Deng A. Association of Renin-Angiotensin System Inhibitors with Severity or Risk of Death in Patients with Hypertension Hospitalized for Coronavirus Disease 2019 (COVID-19) Infection in Wuhan, China. JAMA Cardiol. 2020; 5(7): 825-830. [CrossRef] 
[92] Abajo FJ, Rodríguez-Martín S, Lerma V, Mejía-Abril G, Aguilar M, García-Luque A, et al. Use of renin-angiotensinaldosterone system inhibitors and risk of COVID-19 requiring admission to hospital: a case-population study. Lancet. 2020; 395(10238): 1705-1714. [CrossRef]

[93] Tedeschi S, Giannella M, Bartoletti M, ... Clinical impact of renin-angiotensin system inhibitors on in-hospital mortality of patients with hypertension hospitalized for COVID-19. Clin Infect Dis. 2020; 71(15):899-901. [CrossRef]

[94] Oussalah A, Gleye S, Clerc Urmes I, Laugel E, Callet J, Barbé F, et al. Long-term ACE Inhibitor/ ARB Use Is Associated With Severe Renal Dysfunction and Acute Kidney Injury in Patients With Severe COVID-19: Results From a Referral Center Cohort in the Northeast of France. Clin Infect Dis. 2020; 71(9): 2447-2456. [CrossRef]

[95] Arumugam S, Sreedhar R, Thandavarayan RA, Karuppagounder V, Krishnamurthy P, Suzuki K, et al. Angiotensin receptor blockers: Focus on cardiac and renal injury. Trends Cardiovasc Med. 2016; 26(3): 221-228. [CrossRef]

[96] Silva-Filho JL, Souza MC, Henriques M das G, Morrot A, Savino W, Nunes MP, et al. AT1 receptor-mediated angiotensin II activation and chemotaxis of T lymphocytes. Mol Immunol. 2011; 48(15-16): 1835-1843. [CrossRef]

[97] Sukumaran V, Veeraveedu PT, Gurusamy N, Lakshmanan AP, Yamaguchi K, Ma M, et al. Olmesartan attenuates the development of heart failure after experimental autoimmune myocarditis in rats through the modulation of ANG 17 mas receptor. Mol Cell Endocrinol. 2011; 351(2): 208-219. [CrossRef]

[98] Arumugam S, Thandavarayan RA, Palaniyandi SS, Giridharan V V., Arozal W, Sari FR, et al. Candesartan cilexetil protects from cardiac myosin induced cardiotoxicity via reduction of endoplasmic reticulum stress and apoptosis in rats: Involvement of ACE2-Ang (1-7)-mas axis. Toxicology. 2012; 291(1-3): 139-145. [CrossRef]

[99] Ntountaniotis D, Mali G, Grdadolnik SG, Halabalaki M, Maria H, Skaltsounis A-L, et al. Thermal, dynamic and structural properties of drug AT1 antagonist olmesartan in lipid bilayers. Biochim Biophys Acta. 2011; 1808(12): 29953006. [CrossRef]

[100] Agata J, Ura N, Yoshida H, Shinshi Y, Sasaki H, Hyakkoku M, et al. Olmesartan is an angiotensin II receptor blocker with an inhibitory effect on angiotensin-converting enzyme. Hypertens Res. 2006; 29 (11): 865-874. [CrossRef]

[101] Igase M, Strawn WB, Gallagher PE, Geary RL, Ferrario CM. Angiotensin II at1 receptors regulate ACE2 and angiotensin-(1-7) expression in the aorta of spontaneously hypertensive rats. Am J Physiol - Hear Circ Physiol. 2005; 289(3): H1013-1019. [CrossRef]

[102] Magalhães GS, Gregório JF, Ramos KE, Cançado-Ribeiro ATP, Baroni IF, Barcelos LS, et al. Treatment with inhaled formulation of angiotensin-(1-7) reverses inflammation and pulmonary remodeling in a model of chronic asthma. Immunobiology. 2020; 225(3): 151957. [CrossRef]

[103] Imai Y, Kuba K, Rao S, Huan Y, Guo F, Guan B, et al. Angiotensin-converting enzyme 2 protects from severe acute lung failure. Nature. 2005; 436: 112-116. [CrossRef]

[104] Kuba K, Imai Y, Rao S, Gao H, Guo F, Guan B, et al. A crucial role of angiotensin converting enzyme 2 (ACE2) in SARS coronavirus-induced lung injury. Nat Med. 2005; 11(8): 875-879. [CrossRef]

[105] Penna G, Amuchastegui S, Laverny G, Adorini L. Vitamin D receptor agonists in the treatment of autoimmune diseases: Selective targeting of myeloid but not plasmacytoid dendritic cells. J Bone Miner Res. 2007; 22(Suppl 2): V69-73. [CrossRef]

[106] The RECOVERY Collaborative Group, Dexamethasone in Hospitalized Patients with Covid-19 - Preliminary Report. N Engl J Med. 2021; 384: 693-704. [CrossRef]

[107] Theoharides TC, Conti P. Dexamethasone for COVID-19? Not so fast. J Biol Regul Homeost Agents. 2020; 34(3): 12411243. [CrossRef]

[108] Ghadhanfar E, Alsalem A, Al-Kandari S, Naser J, Babiker F, Al-Bader M. The role of ACE2, angiotensin-(1-7) and Mas1 receptor axis in glucocorticoid-induced intrauterine growth restriction. Reprod Biol Endocrinol. 2017; $15(1): 97$. [CrossRef]

[109] Komesli Y, Burak Ozkaya A, Ugur Ergur B, Kirilmaz L, Karasulu E. Design and development of a selfmicroemulsifying drug delivery system of olmesartan medoxomil for enhanced bioavailability. Drug Dev Ind Pharm. 2019; 45(8): 1292-1305. [CrossRef]

[110] Cecen B, Kozaci LD, Yuksel M, Ustun O, Ergur BU, Havitcioglu H. Biocompatibility and biomechanical characteristics of loofah based scaffolds combined with hydroxyapatite, cellulose, poly-L-lactic acid with chondrocyte-like cells. Mater Sci Eng C. 2016; 69: 437-446. [CrossRef] 